\title{
Tribocorrosion in Ferritic Stainless Steels: an Improved Methodological Approach
}

\author{
D. Abreu ${ }^{a}$,W.M. Silva Jr. ${ }^{a}$,M.A.N. Ardila ${ }^{a}$,J.D.B. de Mello * (D) \\ ${ }^{a}$ Universidade Federal de Uberlândia, Faculdade de Engenharia Mecânica, Laboratório de Tribologia \\ e Materiais, Uberlândia, MG, Brasil.
}

Received: April 14, 2021; Revised: August 27, 2021; Accepted: October 19, 2021

\begin{abstract}
This study aimed to improve a potentiodynamic-based methodological approach for characterising the tribocorrosion of ferritic stainless steel. Synergistic effects in tribocorrosion systems have been widely investigated and debated under potentiostatic conditions. Because potentiostatic tests can ignore essential phenomena that are typically noticeable in potentiodynamic tests (potential scanning), such as variations in the friction coefficient that are motivated by potential scanning, e.g., during active, passive, and transpassive domains, a potentiodynamic-technique-based methodology was enhanced to analyse tribocorrosion in ferritic stainless steels. The proposed method facilitates the analysis of all essential parameters for tribocorrosion phenomena based on a single figure directly associating the average friction coefficient curves from sliding tests and tribocorrosion tests. It consists of performing sliding tribological tests to evaluate mechanical wear accurately, potentiodynamic corrosion tests to determine corrosion resistance in the absence of mechanical wear, and tribocorrosion tests to associate mechanical wear and corrosion degradation caused by chemical/electrochemical effects. Validation of the methodology consisted of its application to an $11 \% \mathrm{Cr}$ ferritic stainless steel. The results demonstrate that tribocorrosion intensifies the material loss, but only by a minimal amount. The results demonstrate that the average passivation current density in the tribocorrosive tests was significantly higher. Apparently, the corrosion products generated during the tribocorrosion tests acted as solid lubricants inducing a lower friction coefficient in the tribocorrosive tests. Finally, tribocorrosion intensifies the material loss, but only by a minimal amount.
\end{abstract}

Keywords: Tribocorrosion, potentiodynamic, ferritic stainless steels, methodological approach, sliding wear.

\section{Introduction}

In various tribosystems, the materials in contact are not only under mechanical wear, but can also be exposed to corrosive environments. Such tribosystems are exemplified by orthopaedic implants, chemical pumps, and food processing or mining equipment.

Under such conditions, the wear rate and friction coefficient of tribological contacts cannot simply be predicted based on wear resistance in the inexistence of corrosion or corrosion resistance in the absence of friction. This is because these parameters are not independent of each other and their synergistic effects can increase the material removal rate ${ }^{1}$.

Although tribocorrosion includes a wide variety of mechanical degradative phenomena and wear accelerated by corrosion, erosion-corrosion, oxidative wear, and abrasion in corrosive environments, the literature frequently uses this term to refer strictly to sliding contact in corrosive environments ${ }^{2}$. Figure 1 presents a tribosystem classification chart that considers both mechanical and corrosive effects. As a first approach, the presence of harsh particles was considered as the primary classification criteria. Thus, wear that occurs when two solid surfaces slide over each other ${ }^{3}$ associated by corrosive processes is classified as tribocorrosion, while mechanical wear associated with the presence of hard particles

*e-mail:ltm-demello@ufu.br will have denominations derived from the action of these particles. Thus, when corrosion is related to the removal of material by hard particles, or sometimes by hard protuberances on a counter-face, we will have abrasion-corrosion, whereas, in erosion-corrosion, the degradation is produced by hard particles striking the surface, either carried by a gas stream or entrained in a flowing liquid associated with corrosion.

Electrochemical methods have been widely used to study tribocorrosion phenomena because the mechanical and electrochemical conditions in such systems are well defined and such techniques can easily distinguish these types of conditions. The simulation of corrosive effects in an environment based on the application of external potential outputs a current. Therefore, electrochemical methods facilitate in situ real-time analysis of the quantity of metal turned into oxides or dissolved ions based on simple current density measurements ${ }^{4}$.

The simultaneous use of instruments typically used in corrosive (potentiostats) and tribological (tribometers) studies allows for carrying out tribocorrosive tests.

Over the last few decades, interest in tribocorrosion studies has notably increased, and several electrochemical techniques have been adapted to tribocorrosion research. Until 2016, the only existing standard to study tribocorrosion and determine the synergism between wear and corrosion was the 


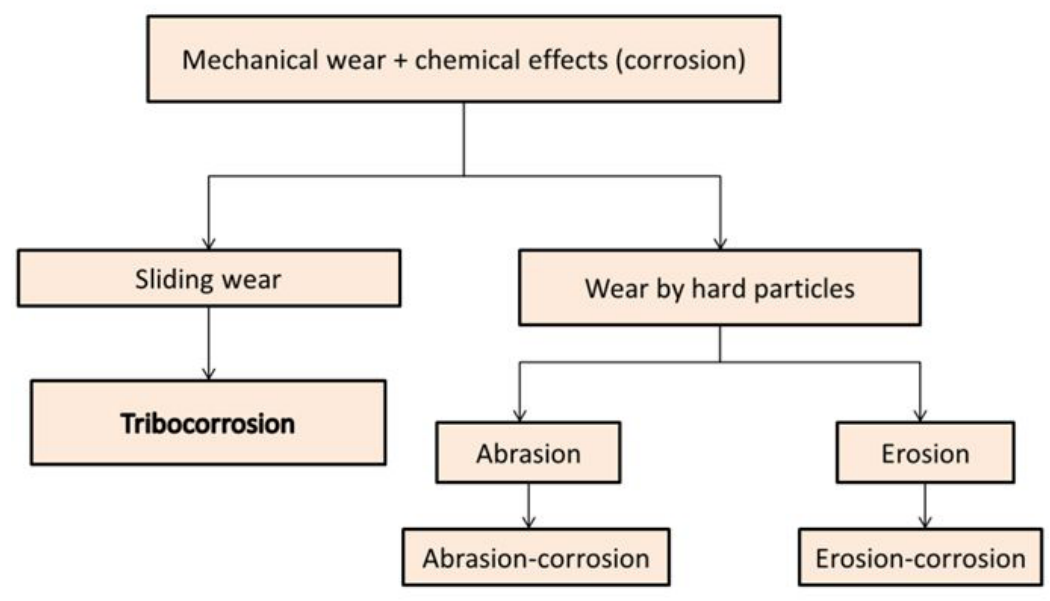

Figure 1. Simultaneous mechanical and corrosive tribosystem.

ASTM G119. ${ }^{5}$. In this recent paper, in addition to critically analyse the existing methods, the authors compile the recent progress acquired by combining different test procedures and electrochemical techniques, among them potentiodynamic polarization tests, potentiostatic polarization tests, or even a combination of both techniques.

Most of the methodologies developed for the study of tribocorrosion consider potentiostatic conditions (predetermined and fixed applied potential) to analyse tribocorrosive behaviours and their synergic effects. By using such techniques, it is possible to control the electrochemical parameters of a system, unlike systems under potentiodynamic conditions, where the electrochemical conditions of systems change continuously according to the potential scanning applied by the potentiostat. Furthermore, the literature is scarce in specific methodologies for associating changes in tribological parameters, such as friction coefficients and wear mechanisms, because only potential scanning is performed, which means that the correlation of such changes with possible synergic effects in tribosystems may be ignored ${ }^{2,4}$.

However, there have been reports of specific potentiodynamic methodologies for characterising the effects of abrasion-corrosion on ferritic stainless steel. Santos et al. ${ }^{6}$, Labiapari et al. ${ }^{6,7}$ and Ardila et al. ${ }^{8}$ described abrasion-corrosion in austenitic and ferritic stainless steels. In addition, some authors studied tribocorrosion under sweeping potential (potentiodynamic condition) of different materials: duplex surface treatments consisting of plasma nitriding and DLC coating 9 , low temperature nitrided austenitic and duplex stainless steels ${ }^{10}$, duplex stainless steel ${ }^{4}, 316 \mathrm{~L}$ stainless steel ${ }^{11,12}$.

In recent years, ferritic stainless steels have been proposed as a competitive alternative for bio-fuel ${ }^{13}$ and concrete mixer industries ${ }^{14}$. Due to its low chromium content, green ferritic stainless steels may provide a sustainable, cost-effective solution in tribosystems subjected to mechanical wear associated with a corrosive medium, particularly when compared to traditional stainless steels (owing to their low cost) or even commonly used carbon steels once the use of materials having a longer useful life present a production chain more environmentally friendly.
In this article, we report an enhanced potentiodynamic methodology for evaluating the tribological behaviours of ferritic stainless steels in tribocorrosive environments. The proposed method facilitates the analysis of all essential parameters for tribocorrosion phenomena based on a single figure directly associating the average friction coefficient curves from sliding tests and tribocorrosion tests. Validation of the developed methodology consisted of its application to an $11 \% \mathrm{Cr}$ ferritic stainless steel.

\section{Experimental Procedure}

As shown in Figure 2, the proposed methodology for studying the synergy and tribological parameters associated with tribocorrosion effects under potential scanning consists of performing three different types of experiments: sliding wear tests to evaluate mechanical wear, corrosion tests to determine corrosion resistance, and tribocorrosion tests to associate mechanical wear and corrosion degradation from chemical/electrochemical effects. Furthermore, wear mechanisms are analysed using scanning electron microscopy (SEM). Validation of the developed methodology consisted of its application to an $11 \% \mathrm{Cr}$ ferritic stainless steel.

\subsection{Materials}

The chemical compositions of the specimens were determined using different types of equipment depending on the elements under analysis. Carbon was detected via infrared absorption using a Leco CS444® device. Nitrogen was detected via thermal conductivity analysis using a Leco TC436 ${ }^{\circ}$ device. All other elements were detected via optical emission spectrometry using a ThermoARL 4460 device.

Microstructures were analysed using the methodology detailed in ${ }^{15}$ and exemplified below. For the metallography, a sanding step was first performed with \#120, \#220, \#320, \#500 and \#600 sandpapers. Polishing, after sanding, was done on the DP-Plancom cloths in a 9,3 and $1 \mu \mathrm{m}$ diamond paste solution in the Struers Abramin-B polishing machine. For the metallographic attack, Vilella reagent was used for a period of 80 seconds. An Image Analyser by Leco was 


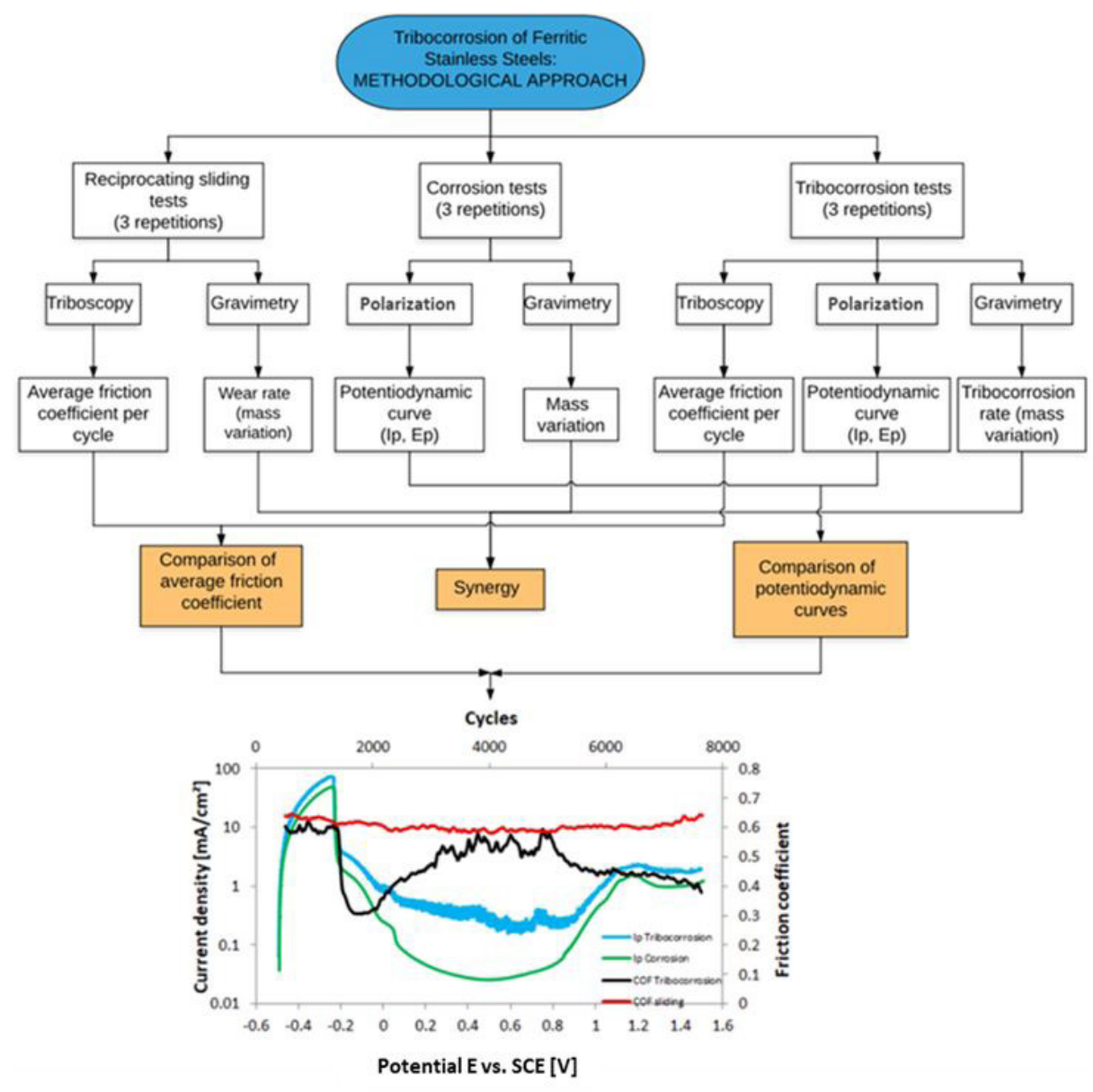

Figure 2. Schematic of the proposed methodology.

used, composed of a LEITZ DMRXE microscope and the $I A 3001 \AA$ analysis software, in order to make a qualitative evaluation of the material structure.

All samples were cut into plates with dimensions of $50 \times 50 \times 5 \mathrm{~mm}$. The preparation for all tests consisted of sanding using SiC sandpaper (\#120,\#220,\#320,\#500, and \#600 grit sandpaper, in order) to produce a uniform surface finish $(\mathrm{Sq}=1.06 \mu \mathrm{m})$ and ultrasonic cleaning with acetone for $15 \mathrm{~min}$. At least three trials were performed for each type of experiment.

\subsection{Methodological approach}

An electrochemical cell (schematically represented in Figure 3) was specially designed, constructed, and adapted to a Phoenix-Plint TE 67 tribometer.

It should be noted that all experiments (corrosive, sliding wear, and tribocorrosive) were performed using this electrochemical cell. Further information regarding the electrochemical cell design and its construction can be found $\mathrm{in}^{15}$. The reliability of the results was evaluated via one-way analysis of variance (ANOVA) using the $\mathrm{Excel}^{\mathbb{B}}$ software.

\subsubsection{Corrosion tests}

Corrosion tests were performed under potential scanning applied by a potentiostat (Biologic SP150) and associated with the agitation effects imposed by reciprocating movement (frequency of $2 \mathrm{~Hz}, 5 \mathrm{~mm}$ stroke). However, the agitation induced by the reciprocal movement can increase the oxygen supply or affect the stability of the tribolayer ${ }^{16}$ the main reason for imposing this movement was to ensure that the same fluid-dynamic conditions active in tribocorrosive tests are present in corrosive experiments. As a point of comparison with tribocorrosive tests, these effects are considered to be essential and cannot be ignored because they are also present in tribocorrosive experiments. Therefore, it is reasonable to compare the potentiodynamic curves of both types of experiments, because any increase in electron excitation caused by the agitation that leads to higher corrosion rates, so the agitation must be present in both types of experiments thus allowing to compare the potentiodynamic curves of two kinds of procedures. For a similar approximation of electron excitation, the sphere holder was positioned such that the sphere did not contact the specimen in our experiments. 


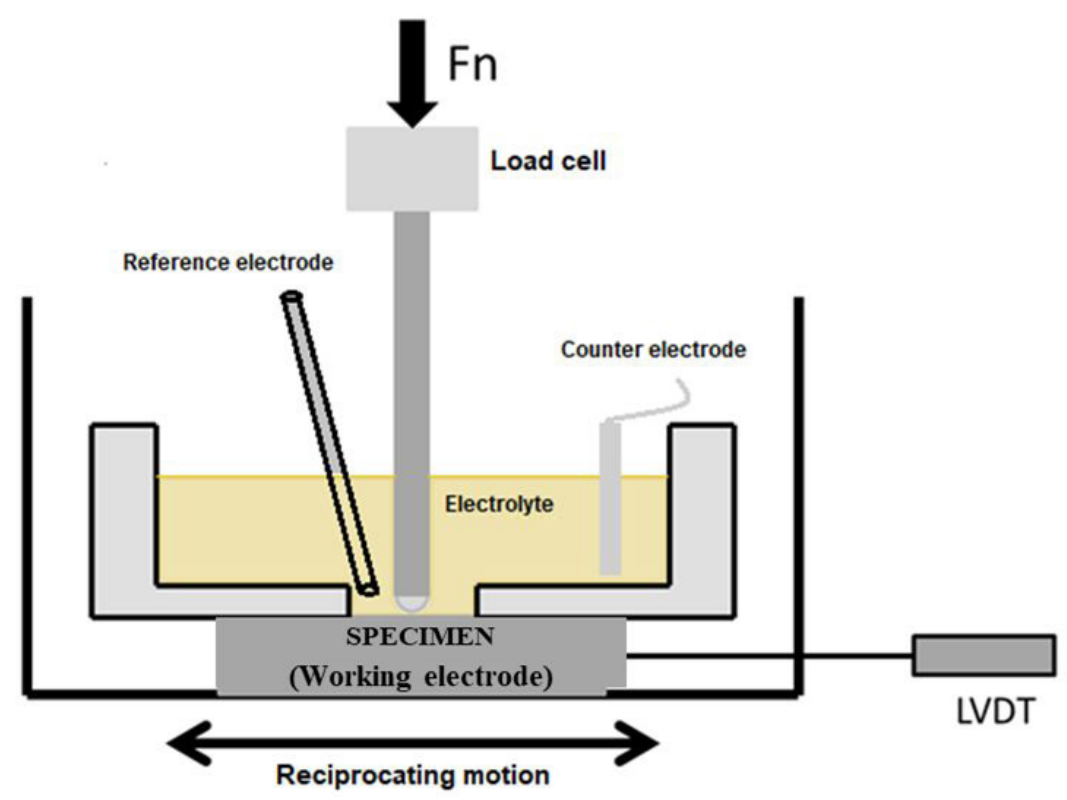

Figure 3. Tribometer adapted to perform tribocorrosive experiments.

Based on potentiodynamic curves, it is possible to obtain relevant parameters that elucidate the corrosive characteristics of a material. In this study, two critical parameters were analysed in detail, namely the passivation current density (ip), which is the lowest current observed in the passive domain and passivation potential (Ep), the potential that characterize the beginning of the passive domain.

Based on potentiodynamic curves, it is possible to obtain relevant parameters that elucidate the corrosive characteristics of a material. In this study, two critical parameters were analysed in detail: the passivation current density (ip), which is the lowest current density observed in the passive domain, and passivation potential (Ep), the potential that characterizes the beginning of the passive domain.

The potentiostat used in our tests was equipped with the acquisition and data processing software $E C L a b^{\circledR} V 10.18$ and EC Lab Express ${ }^{\circledR}$ V5.4, respectively. Its quiescent potential range was $\pm 2.0 \mathrm{~V}$.

The corrosion cell fabricated from an inert material $\left(\right.$ Nylon 6.6 ${ }^{\circledR}$ ) (schematized in Figure 4) has a circular hole in which the specimen is exposed to $30 \mathrm{ml}$ of $1 \mathrm{~N} \mathrm{H}_{2} \mathrm{SO}_{4}$ in a distilled water electrolyte. This volume of electrolyte is necessary to ensure that the Lugin capillary remains in contact with the fluid while maintaining a distance of $2 \mathrm{~mm}$ from the specimen surface. Electron flow can be detected using the counter-electrode (Platinum gauze) circuitry. The reference electrode was a saturated calomel electrode (SCE) and and the specimen was the working electrode.

To ensure good repeatability between tests, each test was conducted within an 8 to $12 \mathrm{~h}$ interval after the entire preparation (sanding and cleaning) of the specimens. This constraint was enforced to control the growth of passivation layers and the stability of polarisation curves ${ }^{17}$.

The corrosion experiments started 10 minutes after immersion in the electrolyte to stabilize the system at the open-circuit potential. The potential scanning was performed

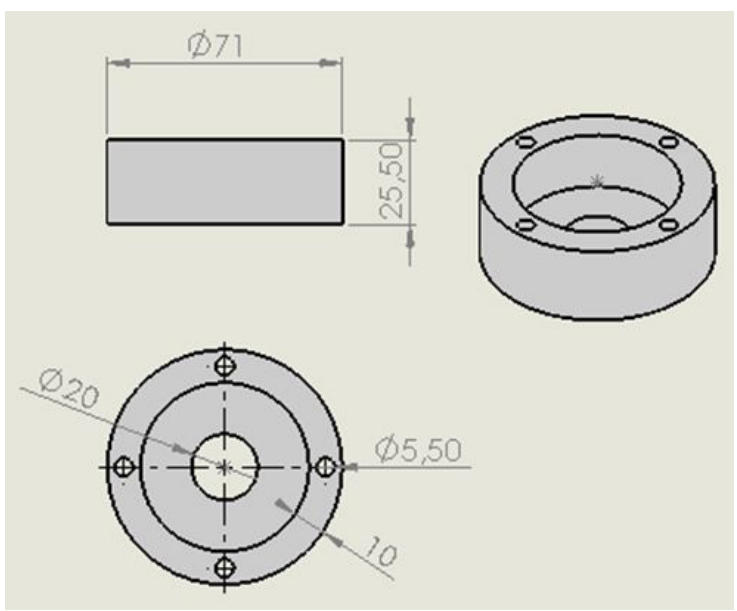

Figure 4. Corrosion cell specially designed for this work (schematic).

under $1.1 \mathrm{mV} / \mathrm{s}$. This value is close to what is found in the literature ${ }^{18}$. Therefore, considering the quiescent range of potential application, the initial potential was fixed at $-0.1 \mathrm{~V}$ in relation to OCP. The final potential was set at $2.0 \mathrm{~V}$ relatively to the open circuit potential (OCP), which was around $-0,5 \mathrm{~V}$, was established as the reference potential. Therefore, the duration of each test was $32 \mathrm{~min}$, starting from the moment of stabilisation of the open circuit potential.

To determine the wear rate from sliding tests, the material loss from corrosion tests and the tribocorrosion rate from tribocorrion tests, the mass of each specimen was measured three times before and after each test using a Sartorius MC210S precision scale $(0.01 \mathrm{mg})$. It is important to note that the full analysis of any tribological contact has to consider the body and counterbody wear track to precisely investigate and correctly interpret the final results. However, using the 
SEM available in our laboratory, the counterbody wear track was indiscernible. Moreover, no mass loss was detected even using the Sartorius MC210S precision scale $(0.01 \mathrm{mg})$.

\subsubsection{Reciprocating sliding tests}

Reciprocating sliding tests, which are schematically illustrated in Figure 2, were performed using a Phoenix-Plint TE 67 tribometer with an oscillation frequency of $2 \mathrm{~Hz}$, $5 \mathrm{~mm}$ stroke, normal load of $10 \mathrm{~N}$, and test time of $32 \mathrm{~min}$. We used $5 \mathrm{~mm}$ zirconia balls $(\mathrm{Sq}=0.23 \mu \mathrm{m})$ as counter bodies. This tribometer contains a load cell for friction force measurement and a linear variable differential transformer (LVDT) sensor for measuring the relative position between the specimen and counter bodies during experiments. This device allows the triboscopic technique to be applied ${ }^{19}$.

Each test began $10 \mathrm{~min}$ after the stabilisation of the friction coefficient (i.e., the data collected did not include the running-in period). However, the mass loss is obtained from the difference of the initial mass (prior to the test) and the final mass (after the test) which means that the material loss from the running in period is also considered to ensure a consistent duration for all experiments, the duration for these tests was set to $32 \mathrm{~min}$.

For close comparisons between the reciprocating sliding tests and tribocorrosion tests, distilled water was used as a lubricant. According to Santos et al. ${ }^{6}$ distilled water is considered a neutral environment for stainless steel. Therefore, its corrosive effects can be ignored for such materials. As a result, only the mechanical component of wear has a significant influence on tribological parameters under such conditions. Moreover, water might also contribute to eliminating heat from the contact between the specimen and the counterbody, and, additionally, it can remove debris from the contact interface. Considering all these important roles the fluid can play in a tribological contact, its usage was considered very important and mandatory its inclusion in the sliding tests since they are effectively present in the tribocorrosive tests. It is reasonable to suppose that, for the stainless steels, only the lubrication and fluid-dynamic effects might take place for this sort of tribosystem. However, distilled water can cause corrosive effects over the carbon steel surface. Again, considering that it will be under a far more severe corrosive environment in the corrosive experiment, this mass loss due to the distilled water might be neglected.
Every specimen and counter body had its mass measured three times before and after each test using the same precision balance. At least three experiments were performed for each set of conditions.

Data analysis was performed using triboscopy. A triboscopic image is a tridimensional representation of physical parameters versus time during wear testing. Using an algorithm implemented in MATLAB ${ }^{\circledR}$, triboscopic images can be generated easily ${ }^{19}$. An example triboscopic image is presented in Figure5a, and its average friction coefficient evolution as a function of the number of cycles during testing is presented in Figure $5 \mathrm{~b}$.

\subsubsection{Tribocorrosion tests}

To perform tribocorrosive experiments, the designed electrochemical cell was adapted for a Phoenix-Plint TE 67 tribometer and used simultaneously with a Biologic SP150 potentiostat. Unlike the corrosive tests, the zirconia ball (same sphere used in the reciprocating sliding experiments) was in contact with the specimen and under relative motion. A $1 \mathrm{~N} \mathrm{H}_{2} \mathrm{SO}_{4}$ electrolyte was used.

Specimen preparation followed the same methodology used in the previous experiments. The imposed tribological parameters (normal load, frequency, running duration, and test time) were the same as those used in the reciprocating sliding experiments. The potentiodynamic curves, average friction coefficient as a function of the number of cycles, and $3 \mathrm{D}$ triboscopic images were obtained.

SEM (ZEISS models Leo $940 \mathrm{~A}^{\circledR}$ and Evo MA10 ${ }^{\circledR}$ ) and EDX (TESCAN Vega ${ }^{\circledR}-10 \mathrm{KV}$ ) evaluated the wear mechanisms acting on each type of test. To advance this understanding, in some cases, additional tests interrupted at relevant times were performed. It is important to note that the full analysis of any tribological contact has to consider the body and counterbody wear track to precisely investigate and correctly interpret the final results. However, using the SEM available in our laboratory, the counterbody wear track was indiscernible. Moreover, no mass loss was detected even using a Sartorius MC210S precision balance $\left(10^{-5} \mathrm{~g}\right)$, being unnoticeable by the instruments used.

Figure 6 presents a schematic summary of the methodology used for all experiments. It should be noted that the parameters associated with the tribocorrosive investigation are the same parameters associated with the corrosive and sliding wear

(a)
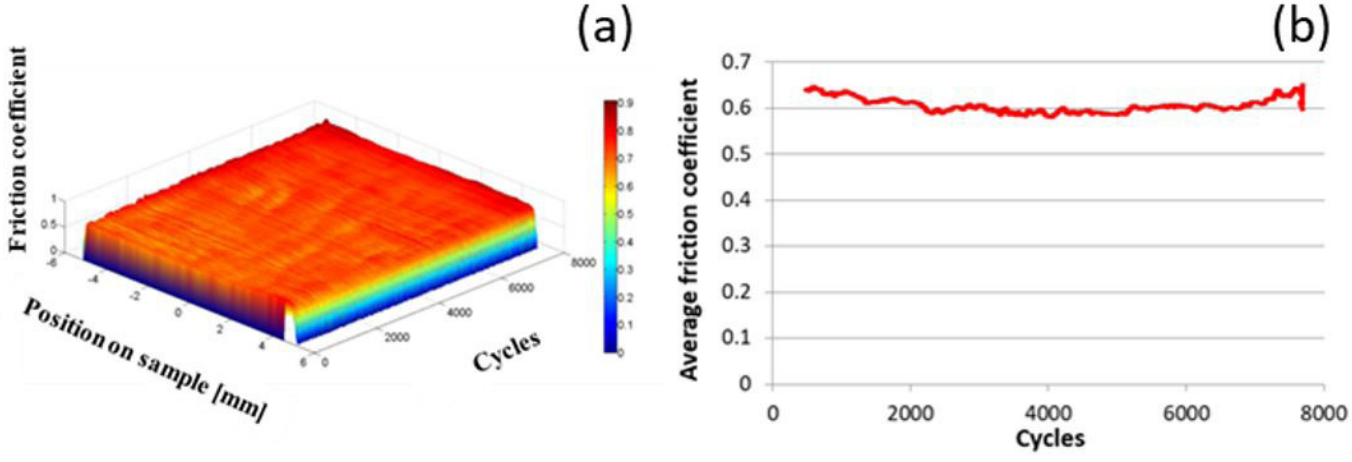

Figure 5. (a) Typical triboscopic $3 \mathrm{D}$ image. (b) Average friction coefficient evolution during testing. 
Table 1. Parameters associated with each experiment.

\begin{tabular}{|c|c|c|c|}
\hline & Corrosion tests & Sliding wear tests & Tribocorrosion tests \\
\hline Movement & Reciprocating (2 Hz, $5 \mathrm{~mm}$ stroke) & Reciprocating ( $2 \mathrm{~Hz}, 5 \mathrm{~mm}$ stroke) & Reciprocating (2 Hz, $5 \mathrm{~mm}$ stroke) \\
\hline Normal load (N) & 0 & 10 & 10 \\
\hline Fluid & $1 \mathrm{~N} \mathrm{H}_{2} \mathrm{SO}_{4}$ & $\mathrm{H}_{2} \mathrm{O}$ & $1 \mathrm{~N} \mathrm{H}_{2} \mathrm{SO}_{4}$ \\
\hline Counter-body & Null & Zirconia ball, $\phi 5 \mathrm{~mm}$ & Zirconia ball, $\phi 5 \mathrm{~mm}$ \\
\hline $\begin{array}{l}\text { Electrochemical } \\
\text { method }\end{array}$ & $\begin{array}{c}\text { Potentiodynamic } \\
\left(-0.6 \mathrm{~V} \text { to } 1.5 \mathrm{~V}, 1.1 \mathrm{mV}^{-1} \mathrm{~s}^{-1}\right.\end{array}$ & Null & $\begin{array}{c}\text { Potentiodynamic } \\
\left(-0.6 \mathrm{~V} \text { to } 1.5 \mathrm{~V}, 1.1 \mathrm{mV}^{-\mathrm{s}^{-1}}\right)\end{array}$ \\
\hline
\end{tabular}

Table 2. Chemical composition of the tested stainless steel (wt \%).

\begin{tabular}{ccccccccccccccccc}
\hline Element & $\mathrm{C}$ & $\mathrm{Mn}$ & $\mathrm{Si}$ & $\mathrm{P}$ & $\mathrm{S}$ & $\mathrm{Cr}$ & $\mathrm{Ni}$ & $\mathrm{Mb}$ & $\mathrm{Al}$ & $\mathrm{Cu}$ & $\mathrm{Co}$ & $\mathrm{V}$ & $\mathrm{Nb}$ & $\mathrm{Ti}$ & $\mathrm{Sn}$ & $\mathrm{W}$ \\
\hline$\%$ & 0.011 & 0.61 & 0.49 & 0.0247 & 0.0002 & 11.23 & 0.31 & 0.021 & 0.002 & 0.022 & 0.008 & 0.006 & 0.003 & 0.0145 & 0 & 0.0145 \\
\hline
\end{tabular}

\begin{tabular}{|c|c|c|}
\hline \multirow{2}{*}{ - Corrosion: } & $10 \mathrm{~min}$ & $32 \mathrm{~min}$ \\
\hline & OCP & Potential scanning \\
\hline \multirow{3}{*}{ - Sliding: } & $10 \mathrm{~min}$ & $32 \mathrm{~min}$ \\
\hline & Sliding - running in & Sliding \\
\hline & $10 \mathrm{~min}$ & $32 \mathrm{~min}$ \\
\hline - Tribocorrosion: & $\begin{array}{c}\text { OCP } \\
+ \\
\text { Sliding }- \text { running in }\end{array}$ & $\begin{array}{c}\text { Potential scanning } \\
+ \\
\text { Sliding }\end{array}$ \\
\hline
\end{tabular}

Figure 6. Methodological summary and duration of all tests.

experiments. Therefore, it is possible to evaluate the synergistic effects of tribocorrosion by comparing the results obtained from these experiments. Moreover, Table 1 synthesizes all parameters associated with each experiment.

\section{Results and Discussion}

The designed electrochemical cell proved to be appropriate for the corrosive and tribocorrosive experiments. The electrodes could be fixed without movement as the experiments were performed, so the measurement of current density was not compromised. All tests exhibited excellent repeatability according to the results of analysis of variance (ANOVA) ${ }^{17}$.

As indicated previously, our methodology was applied to an AISI 410 stainless steel. Its microstructure, which is presented in Figure 7, is ferritic. Its chemical composition is provided in Table 2 .

\section{1. 'Static corrosion' and 'non-static corrosion'}

Figure 8 presents the potentiodynamic curves and main electrochemical parameters (passivation current density (ip) and passivation potential (Ep) obtained during corrosive tests performed under static and non-static conditions (i.e., with and without relative movement of the electrolyte). These parameters were selected to evaluate the electrochemical behaviour because passivation current density (ip) is, in a way, an indication of the corrosion resistance, and the passivation potential (Ep) establishes the beginning of the passive regime. ANOVA results with $95 \%$ reliability demonstrate that both

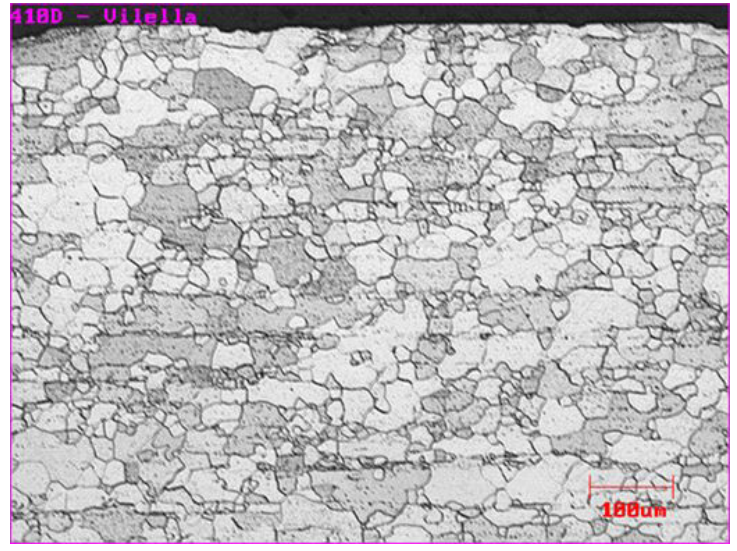

Figure 7. AISI 410 steel typical microstructure.

parameters (ip and Ep) can be considered the same under both conditions. Therefore, the 'non-static' condition was selected for further investigation. It is worth mentioning that since we did not use the results from static corrosion for the final analysis, it was not mentioned in the experimental section.

\subsection{Friction coefficient}

When comparing the $3 \mathrm{D}$ triboscopic images acquired from the sliding wear and tribocorrosion tests (Figure 9), it might be seen that the corrosive component plays an important role in the friction coefficient, changing its behaviour significantly 

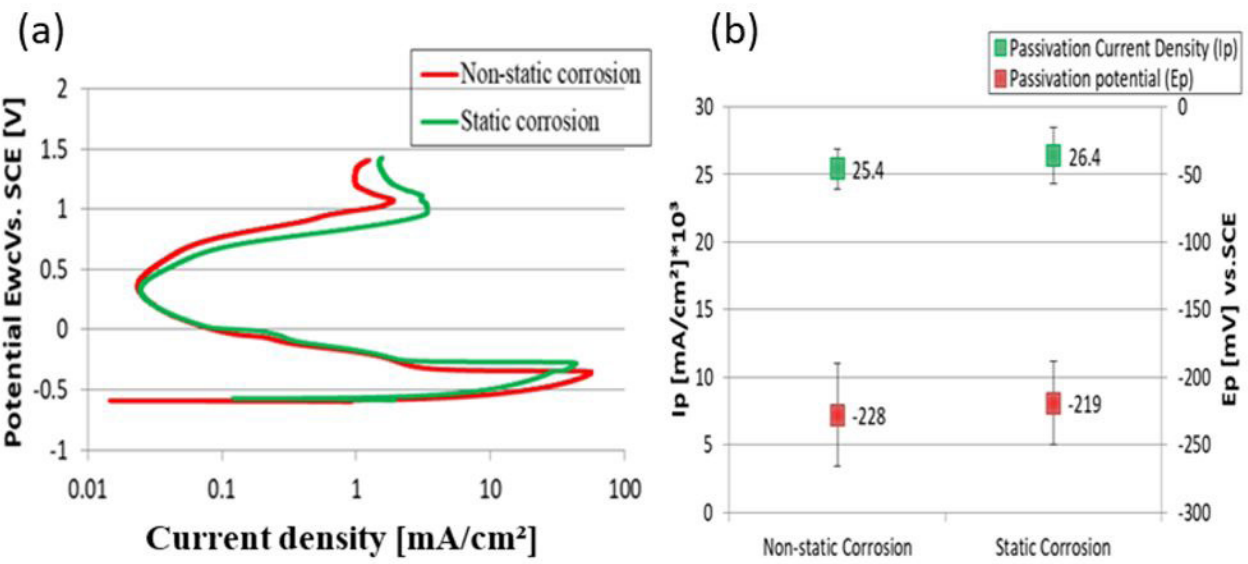

Figure 8. Non-static corrosion and static corrosion. (a) Potentiodynamic curves. (b) Comparison of the parameters ip and Ep.
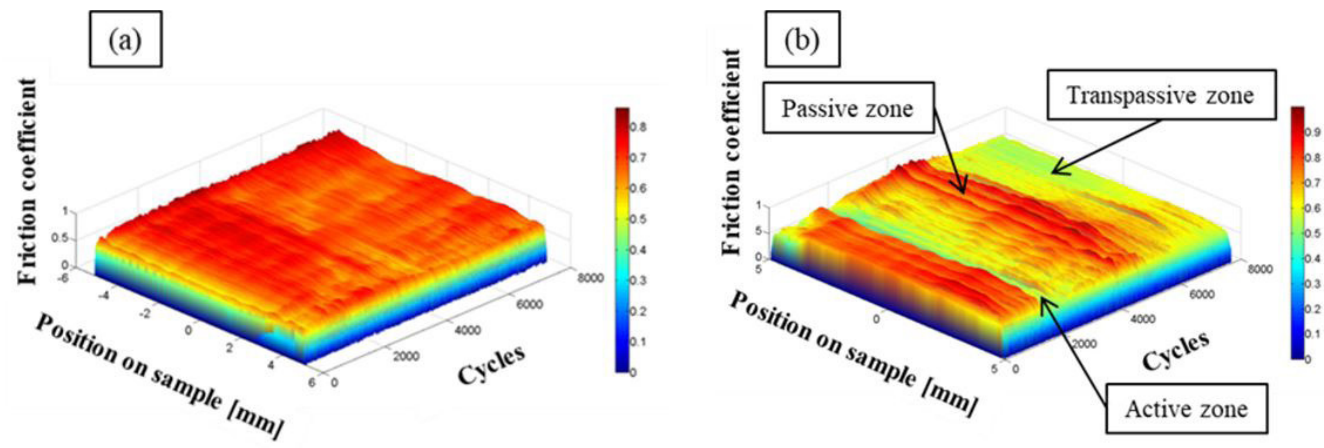

Figure 9. 3D triboscopic maps. (a) Sliding wear test. (b) Tribocorrosive test.

during potential scanning. Variations occur not only within each cycle, but also with an increase in the number of cycles which in turn is tied to the potential scan. These fluctuations correspond to the different passivation stages of the corrosive phenomenon (Figure 9b). One can also see that the friction coefficient remains virtually constant under pure sliding wear (Figure 9a). Such behaviour was expected because the electrochemical conditions of the contact were the same over the entire duration of the tests. Therefore, it is reasonable to conclude that the wear mechanism was the same over the entire duration of the tests. Figure 10 reveals that the predominant wear mechanism is abrasion, as indicated by grooves (red arrows), probably created by hard wear debris formed by highly deformed and oxidized wear products and from particles of the oxide layer itself (passive layer). Additionally, energy-dispersive X-ray spectroscopy (EDS) analysis revealed the presence of zirconium in the valleys, indicating the formation of tribolayers containing material from the counter body.

In contrast, in the tribocorrosion tests, the friction coefficient was strongly influenced by the corrosive component associated with potential scanning. Figure $9 \mathrm{~b}$ reveals that the friction coefficient is initially high and that its value is close to that observed under the sliding conditions because mechanical wear is dominant in both types of tests. However,

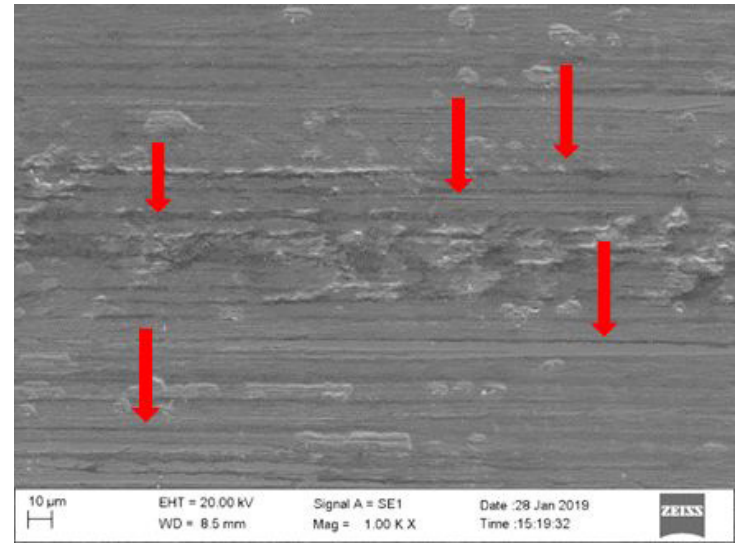

Figure 10. Typical wear scar from a sliding wear test (SEM micrograph).

after approximately 2000 cycles, the friction coefficient drops significantly in the active zone, where metal dissolution is high. Shortly thereafter, the friction coefficient increases again in the passive zone, where the dissolution of metal is suppressed by passive layer growth in that potential range. In the transpassive zone, the passive layer is no longer 
present, as evidenced in the analyzes of the wear marks of the interrupted tests $1.5 \mathrm{~V}$ reported further, which could be the reason for the significant decrease in the friction coefficient.

This unstable behaviour of the friction coefficient during tribocorrosion testing resulted in a lower average friction coefficient compared to that obtained from the sliding wear tests (Figure 11). This discrepancy can be attributed to the electrochemical factors that generate corrosion products, which can act as solid lubricants in the contact area ${ }^{8-20}$, as recently demonstrated by Labiapari et al. ${ }^{7,21}$ under abrasioncorrosion conditions. For steels in sulfuric acid tribocorrosive systems, iron dissolves and the compound $\mathrm{Fe}_{2} \mathrm{SO}_{4}$ is formed on the metal surface according to Equation 1.

$\mathrm{Fe}_{(\mathrm{s})}+\mathrm{H}_{2} \mathrm{SO}_{4(\mathrm{aq})} \rightarrow \mathrm{Fe}_{2} \mathrm{SO}_{4(\mathrm{aq})}+\mathrm{H}_{2(\mathrm{~g})}$

Labiapari et al. ${ }^{7}$ used Fourier transform infrared spectroscopy and associated the reduction in the friction coefficient with rich tribofilm formation. Such a film acts as an extreme pressure agent in the contact zone. Furthermore, according to Mischler et al. ${ }^{20}$, the thickness of this tribofilm is on the order of 1 to $2 \mathrm{~nm}$ and its existence in the contact zone softens the surface under the action of the corrosive environment.

It is reasonable to assume that the variations in the friction coefficient associated with the fluctuations in the

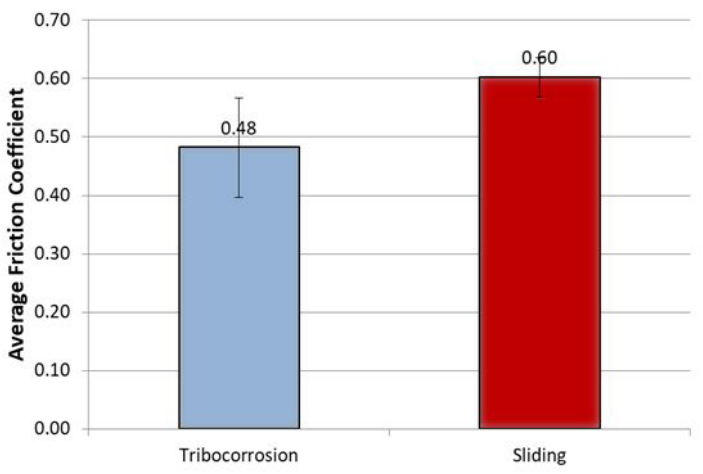

Figure 11. Average friction coefficients. potential in Figure 9b stem from changes in electrochemical conditions in the contact zone, which also induce changes in degradation mechanisms. Figure 12 presents the wear marks from tribocorrosive tests interrupted at different potentials ranging from $-0.1 \mathrm{~V}$ (Figure $12 \mathrm{a}$ ), where the friction coefficient is the lowest, to $0.5 \mathrm{~V}$ (Figure 12b), where the friction coefficient is the highest in the passive zone, and $1.5 \mathrm{~V}$ (Figure 12c), where the friction coefficient begins to decrease again at the end of testing.

Figure 12a presents an SEM image from the interrupted test at $-0.1 \mathrm{~V}$. Generalized corrosion associated with plastic deformation and fracture is visible across the rough surface, but no abrasion marks are noticeable. Figure $12 \mathrm{~b}$ shows a smooth surface with no material detachment, which can be attributed to the formation of a passive layer that prevents metal dissolution. Finally, Figure 12c presents the wear surface in the transpassive zone, where abrasion marks (indicated by the red arrows) dominate as the wear mechanism across the surface.

EDS analysis $(10 \mathrm{kV})$ results (Figsure 13b, c) allow us to infer that there is no transference of material from the counter body (zirconium) to the specimen surface at the potential of $-0.1 \mathrm{~V}$.

The EDS analysis (10kV) (Figure 14) results for potentials of $0.5 \mathrm{~V}$ (higher friction coefficient) and $1.5 \mathrm{~V}$ (end of the test) also indicate no transference of material from the counter body to the specimen, meaning zirconium is not apparent at any of the potentials analysed. Therefore, it is reasonable to conclude that with the utilised techniques, no zirconiumrich tribolayer was formed during the tribocorrosive tests.

\subsection{Passivation current density (ip) and passive potential (Ep)}

A considerable difference is noticeable (Figure 15) when comparing the average passivation current density from the tribocorrosive test to the average passivation current density from the corrosive test. The passive current obtained from the tribocorrosive test ip $=0.384 \frac{\mathrm{mA}}{\mathrm{cm}^{2}}$ ) is considerably higher (order of magnitude) than that obtained from the corrosive test (ip $=0.0252 \frac{\mathrm{mA}}{\mathrm{cm}^{2}}$ ).

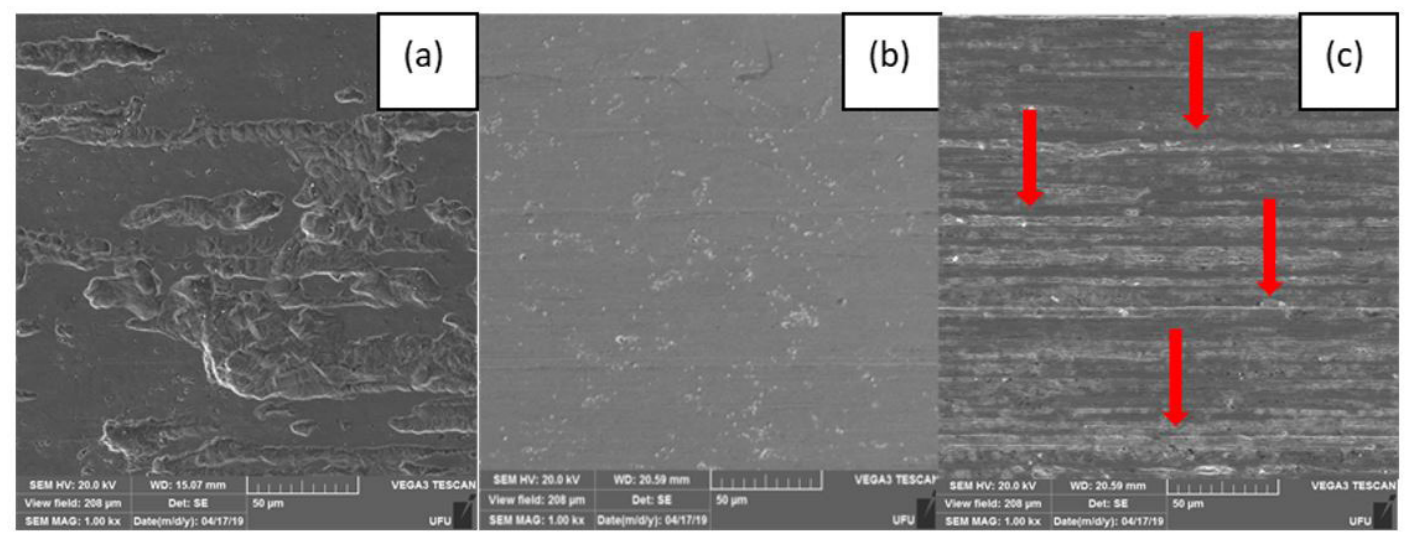

Figure 12. SEM images from interrupted tribocorrosive tests: (a) $-0.1 \mathrm{~V}$, (b) $0.5 \mathrm{~V}$, and (c) $1.5 \mathrm{~V}$. 

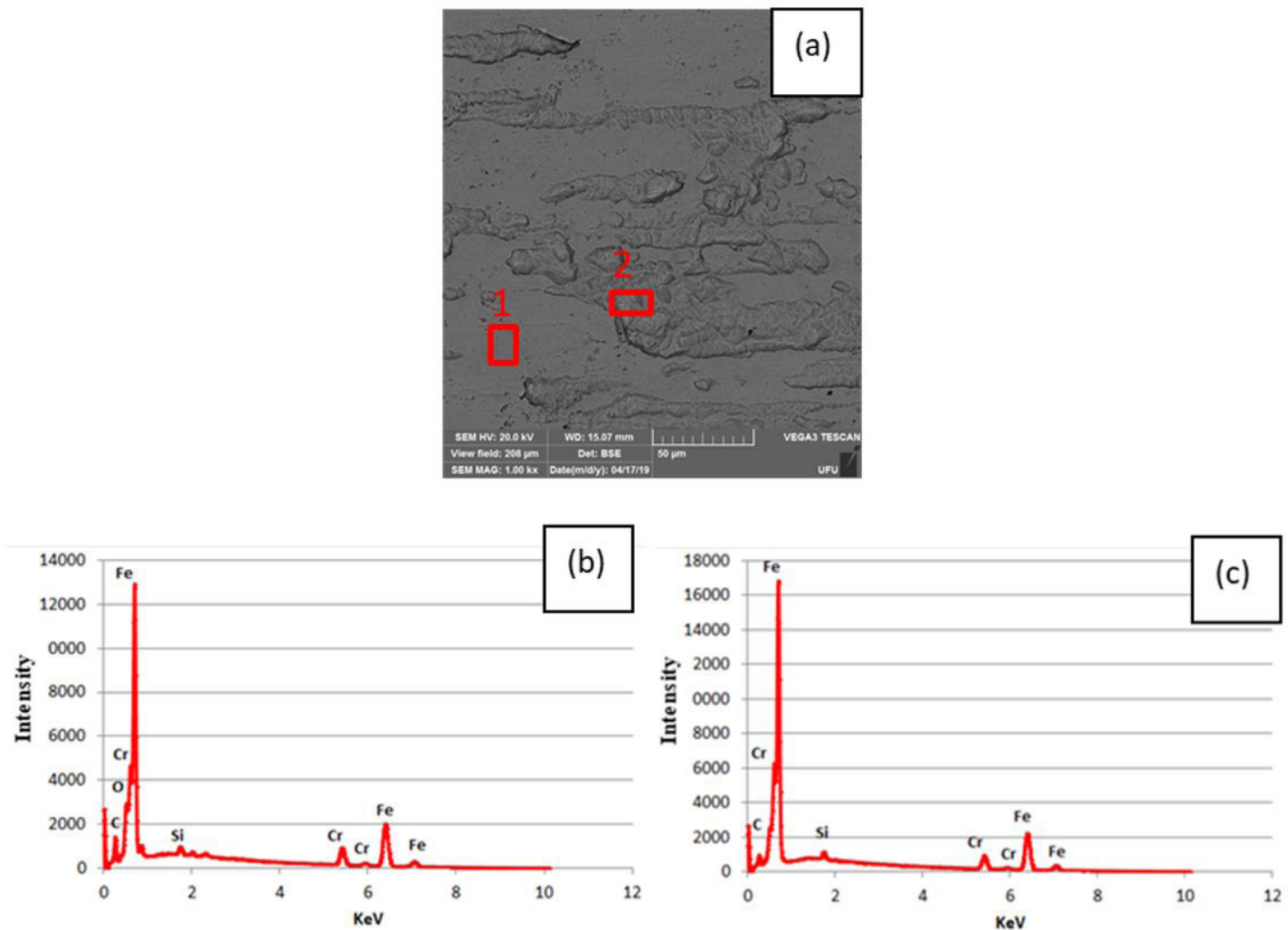

Figure 13. (a) Backscattered electron (BSE) image of the wear track at $-0.1 \mathrm{~V}$ and EDS analysis from (b) Area 1 and (c) Area 2.
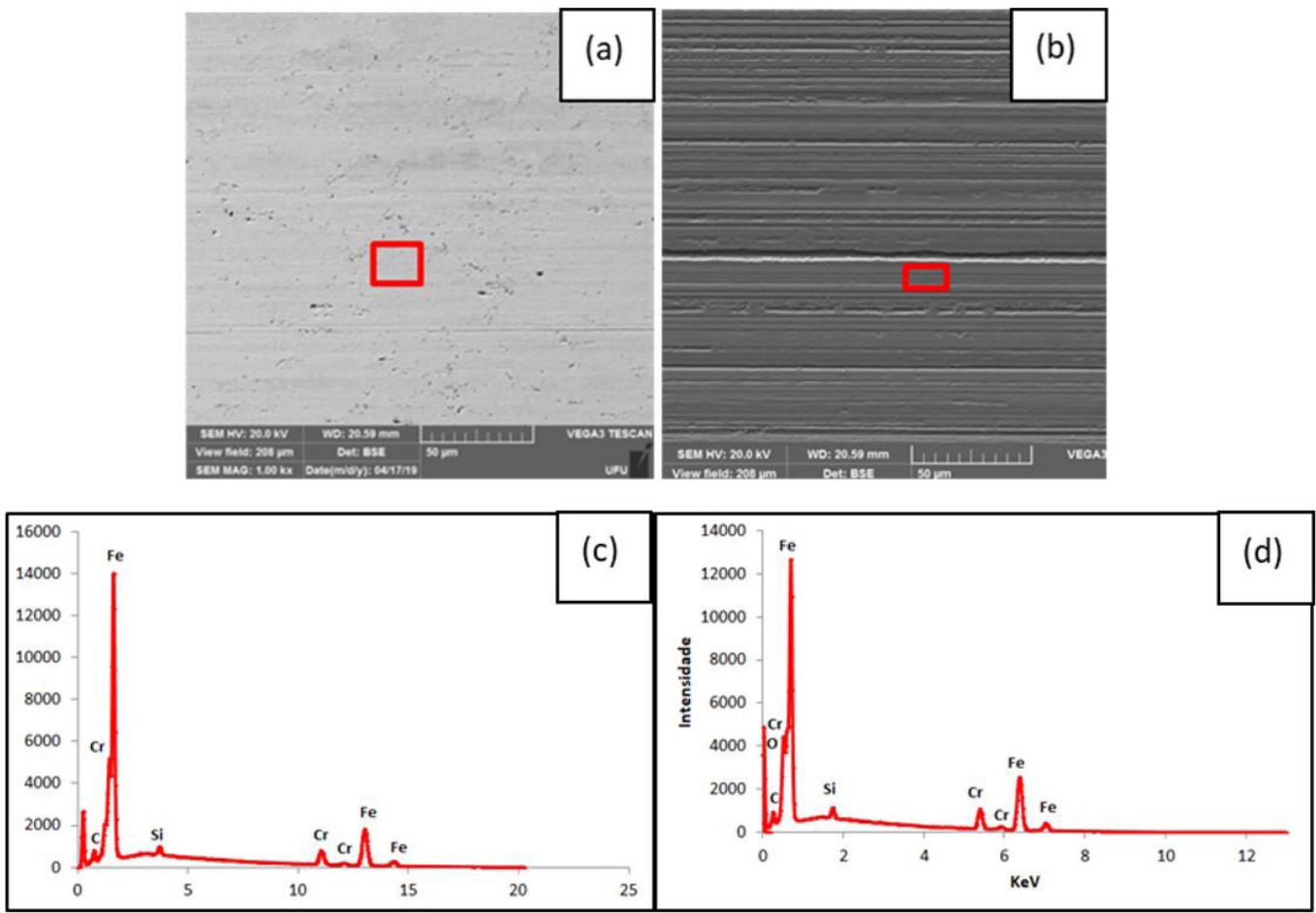

Figure 14. (a) BSE image from the wear track at $0.5 \mathrm{~V}$, (b) BSE image from the wear track at $1.5 \mathrm{~V}$, (c) EDS analysis from the highlighted area in (a) and (d) EDS analysis from the highlighted area in (b). 


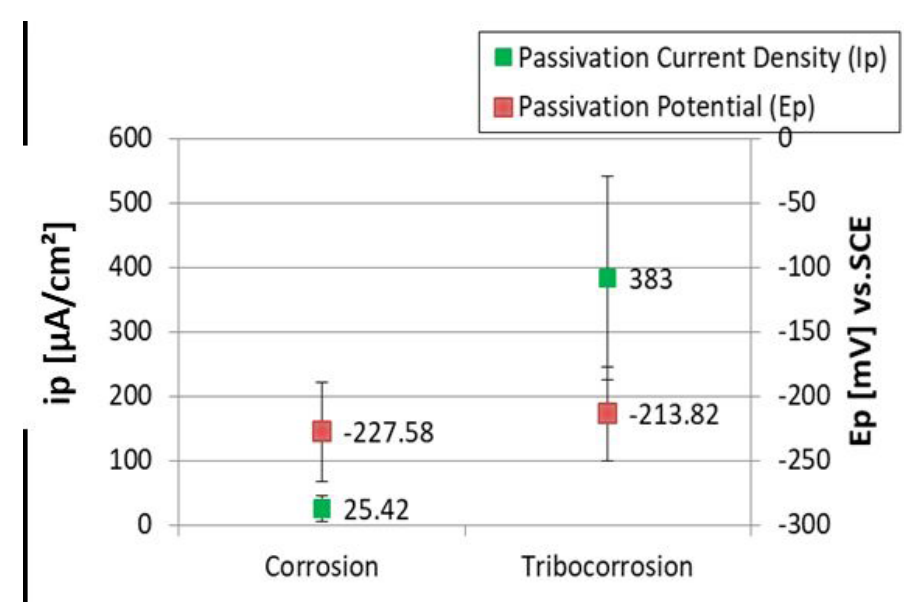

Figure 15. Results of tribocorrosion and corrosion tests.

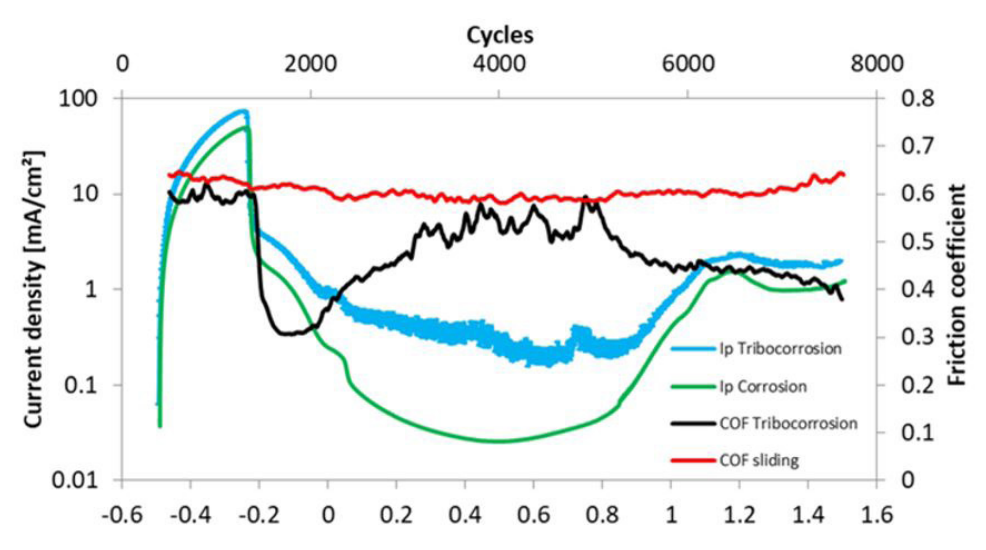

Potential E vs. SCE [V]

Figure 16. Summary of results.

The mechanical component of the tribocorrosive tests increased the passive current, making the material even more susceptible to corrosive effects based on the removal of the passive layer. Consequently, greater exposure to the corrosive environment increased the metal dissolution rate, resulting in more significant mass loss. However, the passive potential does not exhibit any significant changes from one test to the other, as shown in Figure 13 and demonstrated by ANOVA results.

Figure 16 summarizes in an original manner, and in a single graph, the average potentiodynamic curves from the corrosion and tribocorrosion tests and the average curves of the friction coefficient, as functions of the number of cycles in both tests. Although variations in the friction coefficient in the active, passive, and transpassive domains are relatively well known in the field and have been investigated in different media for different active-passive materials using various techniques, The perk of the Figure 16 is the completeness of the information that it can give in a single graph: corrosion parameters and tribological parameters from all experiments.

The type of graph presented in Figure 16 is advantageous in that it facilitates the analysis of all essential parameters for tribocorrosion phenomena based on a single figure.
By comparing the average friction coefficient curves from sliding tests and tribocorrosion tests directly, it is easy to visualise how electrochemical variations influence this parameter in the contact zone between the body and counter body during potential scanning.

Similarly, by comparing the average potentiodynamic curves from corrosion tests and tribocorrosion tests directly, it is simpler and more practical to analyse the influence of the mechanical component of tribocorrosion testing on the potentiodynamic curves. This mechanical component increases the average current density by exposing the bare material to the electrolyte and destroying the passive layer that exists across the surface of the stainless steel ${ }^{22}$.

\subsection{Synergistic effects of tribocorrosion}

Figure 17 presents the wear rate from the tribocorrosive and sliding tests. It is evident that the corrosive environment intensifies wear. However, a direct comparison between these two values may lead to an inaccurate result because in the tribocorrosive experiment the entire active area of the electrochemical cell (schematically represented in Figure 17) is under the effects of corrosion, which contributes to mass loss. In contrast, in the sliding wear test, mass loss is only 


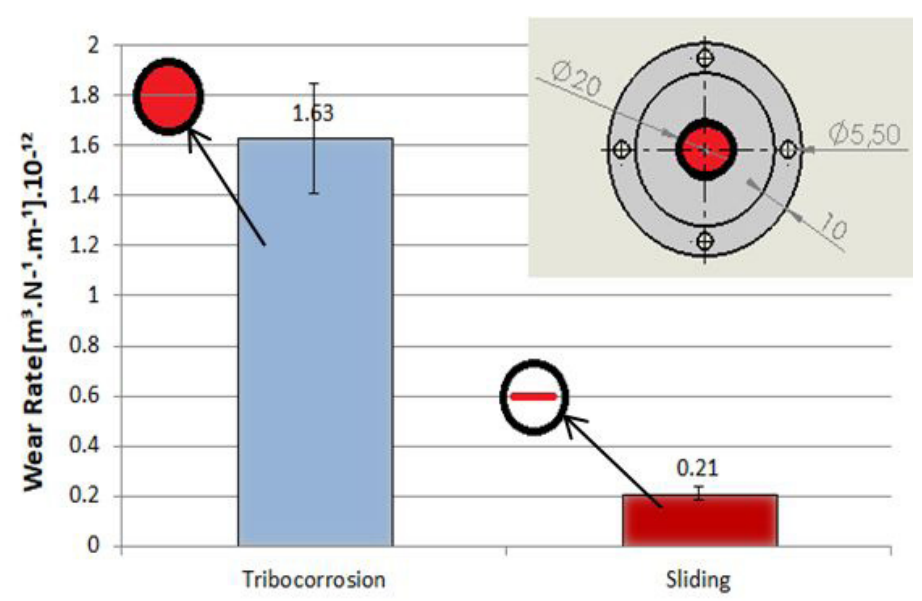

Figure 17. Wear rate from the tribocorrosive and the sliding test. The active area (red area) is indicated.

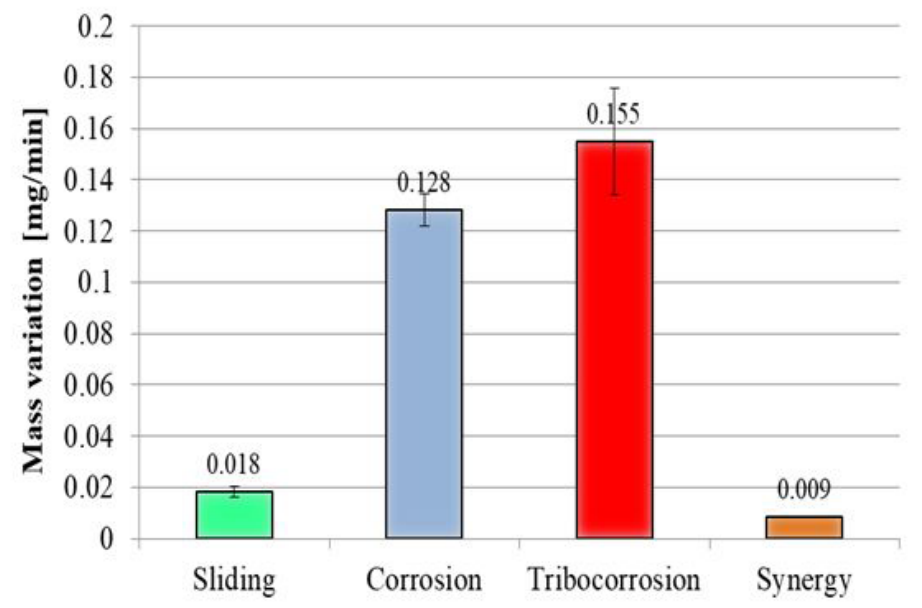

Figure 18. Mass variation and synergistic effect.

attributed to the wear mark caused by the contact of the counter body with the surface of the material.

Considering the mass loss measured in the corrosive test, it is possible to evaluate the synergic effects of the tribocorrosion phenomena because the active area was fully covered in the corrosive test. The synergy between mechanical and chemical components can be determined by summing the mass variations of the sliding and corrosion tests and comparing them to the mass variation of the tribocorrosive test. Therefore, is possible to determine if the synergy is positive (mass loss increased by tribocorrosion), negative (mass loss reduced by tribocorrosion), or non-existent. Equation 2 can be used to quantify the synergistic effects between the mass losses from mechanical and chemical effects during tribocorrosion ${ }^{1}$.

$S=T-W-C$

where $S$ is the synergy ((expressed in mass variation, e.g., mg. $\mathrm{min}^{-1}$ ), given by the difference between the total degradation in situ from tribocorrosion tests, represented by $T$, and the sum of the degradation by mechanical wear, from the sliding tests, plus the degradation by corrosion tests, from the corrosive tests, denoted by $W$ and $C$, respectively. Ponthiaux ${ }^{23}$ also considered two different areas to quantify the synergistic effect and this same methodology, using the Equation 2, was successfully used to evaluate the effect of chromium content and stabilization on tribocorrosion of ferritic stainless steel ${ }^{24}$.

Figure 18 reveals that the synergy is positive, but has a very small magnitude $\left(0.009 \mathrm{mg} \mathrm{min}^{-1}\right)$, which can be directly linked to the similarities between the wear mechanisms acting during the tribocorrosion and sliding tests, as indicated in Figure 19.

The wear marks typically show abrasion marks at the end of both the tribocorrosion and sliding wear tests (Figure 19). At this stage of the test, the formation of a tribolayer and material transfer from the counter body in the wear scars of specimens subjected to tribocorrosion was not observed for the case of tribocorrosion. In this case, corrosion products resultants from the dissolution of materials and debris from counter-body, both the formed oxides and transferred material likely dissolved in the electrolyte during the test ${ }^{25}$. However, mechanically generated, strain-hardened, and oxidized debris continues to act. 

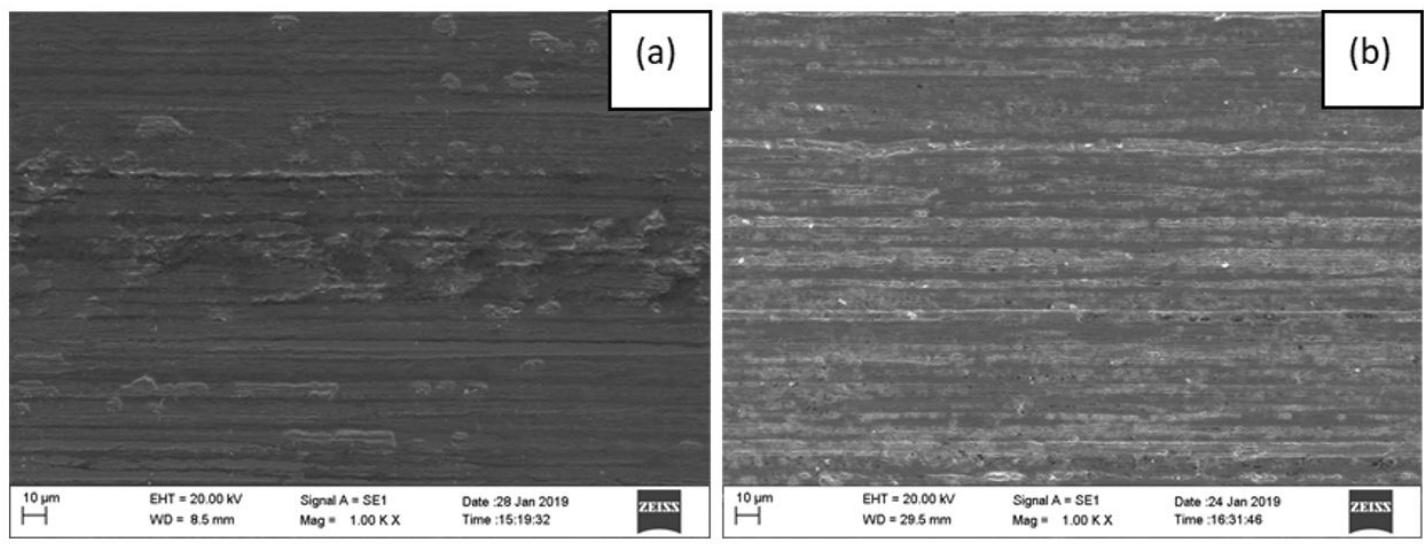

Figure 19. Wear tracks on the $11 \mathrm{Cr}$ from (a) sliding wear and (b) tribocorrosion tests.

\section{Conclusions}

We proposed a potentiodynamic-based methodology for the evaluation of tribocorrosion effects on ferritic stainless steels. The proposed method proved to be simple, reliable, and reproducible. Based on our experimental results, we can draw the following conclusions:

1. The static and non-static corrosion experiments exhibited similar behaviour (i.e., the potentiodynamic curves overlapped at some specific points). In particular, the passivation current density and passivation potential were shown to be statistically equivalent.

2. The average passivation current density in the tribocorrosive tests was significantly higher (order of magnitude) than the average current density in the corrosive experiments.

3. The average friction coefficient in the tribocorrosive tests was lower than the average friction coefficient in the sliding wear tests. Apparently, the corrosion products generated during the tribocorrosion tests acted as solid lubricants on the interface between the specimen and counter body.

4. The synergic effects of tribocorrosion are moderate. This result is attributed to the similarities between the wear mechanisms acting during the tribocorrosion and sliding wear tests.

\section{Acknowledgments}

The authors wish to thank APERAM South America and the Foundation for Research Support of the State of Minas Gerais (Fapemig), Brazil for the financial support.

\section{References}

1. Landolt D, Mischler S, Stemp M. Electrochemical methods in tribocorrosion: a critical appraisal. Electrochim Acta. 2001;46(24-25):3913-29. http://dx.doi.org/10.1016/S00134686(01)00679-X

2. Ponthiaux P, Wenger F, Drees D, Celis JP. Electrochemical techniques for studying tribocorrosion processes. Wear. 2004;256:459-68. http://dx.doi.org/10.1016/S0043-1648(03)00556-8.
3. Hutchings IM, Shipway P. Tribology: friction and wear of engineering materials. 2nd ed. Oxford: Butterworth-Heinemann; 2017.

4. Silva RCC, Nogueira RP, Bastos IN. Tribocorrosion of UNS S32750 in chloride medium: effect of the load level. Electrochim Acta. 2011;56:8839-45. http://dx.doi.org/10.1016/j. electacta.2011.07.077.

5. López-Ortega A, Arana J L, Bayón R. Tribocorrosion of passive materials: a review on test procedures and standards. Int J Corros. 2018;2018:7345346. https://doi.org/10.1155/2018/7345346

6. Santos MB, Labiapari WS, Ardila MAN, Silva WM Jr, Mello JDB. Abrasion-corrosion: new insights from force measurements. Wear. 2015;332-333:1206-14. http://dx.doi.org/10.1016/j. wear.2015.01.002.

7. Labiapari WS, Ardila MAN, Costa HL, Mello JDB. Micro abrasion-corrosion of ferritic stainless steels. Wear. 2017;376377:1298-306. http://dx.doi.org/10.1016/j.wear.2017.01.083.

8. Ardila MAN, Labiapari WS, Costa HL, J Mello JDB. Influence of stainless steel specimen topography on micro-abrasion and micro-abrasion-corrosion. Wear. 2018;426-427:1482-95. http:// dx.doi.org/10.1016/j.wear.2019.01.011.

9. Kovacı H, Bozkurt YB, Yetim AF, Baran Ö, Çelik A. Corrosion and tribocorrosion properties of duplex surface treatments consisting of plasma nitriding and DLC coating. Tribol Int. 2021;156:106823. http://dx.doi.org/10.1016/j.triboint.2020.106823.

10. Haruman E, Sun Y, Adenan MS. A comparative study of the tribocorrosion behaviour of low temperature nitrided austenitic and duplex stainless steels in $\mathrm{NaCl}$ solution. Tribol Int. 2020;151:106412. http://dx.doi.org/10.1016/j.triboint.2020.106412.

11. Kossman S, Coelho LB, Mejias A, Montagne A, Van Gorp A, Coorevits T, et al. Impact of industrially applied surface finishing processes on tribocorrosion performance of $316 \mathrm{~L}$ stainless steel. Wear. 2020;456-457:203341. http://dx.doi. org/10.1016/j.wear.2020.203341.

12. Alkan S, Gök MS. Effect of sliding wear and electrochemical potenti behaviour of AISI 316 stainless steel in seawater. Int J Eng Sci Technol. 2021;24(2):524-32. https://doi.org/10.1016/j. jestch.2020.07.004.

13. Labiapari WS, Alcântara CM, Costa HL, Mello JDB. Stainless steel as an antiwear material for the biofuel industry. Wear. 2013;302(12):1536-45. http://dx.doi.org/10.1016/j.wear.2012.12.023.

14. Labiapari WS, Gonçalves RJ, Alcântara CM, Pagani V, Cunto JC, Mello JDB. Understanding abrasion-corrosion to improve concrete mixer drum performance: a laboratory and field approach. Wear. 2021;477:203830. http://dx.doi.org/10.1016/j. wear.2021.203830. 
15. Labiapari WS, Ardila MAN, Binder C, Costa HL, Mello JDB. Mechanical effects on the corrosion resistance of ferritic stainless steels during micro-abrasion-corrosion. Wear. 2019;426427:1474-81. http://dx.doi.org/10.1016/j.wear.2018.12.057.

16. Matos O, Barcia R, Esteves O, Pebere N, Tribollet B. Anodic dissolution of metals under mass transport control. Electrochim Acta. 1996;41:1385-91. http://dx.doi.org/10.1016/0013-4686(95)00460-2.

17. Abreu D. Tribocorrosão em aços inoxidáveis ferríticos: uma abordagem metodológica [dissertation]. Uberlândia: Universidade Federal de Uberlândia; 2019 [cited 2021 Apr 14]. Available from: https://repositorio.ufu.br/handle/123456789/27204.

18. Ardila MAN, Labiapari WS, Mello JDB. The influence of crystallographic texture and niobium stabilisation on the corrosion resistance of ferritic stainless steel. Mater Res. 2017;20(3):57683. http://dx.doi.org/10.1590/1980-5373-MR-2016-0622.

19. Oliveira MM Jr, Hammes G, Binder C, Klein AN, Mello JDB. Solid lubrication in fluid film lubrication. Lubr Sci. 2018;30(3):102-15. http://dx.doi.org/10.1002/ls.1408.

20. Mischler S, Rosset EA, Landolt D. Effect of Corrosion on the Wear Behavior of Passivating Metals in Aqueous Solutions. Tribology Series. 1993;25:245-53. http://dx.doi.org/10.1016/ S0167-8922(08)70380-8.
21. Labiapari WS, Ardila MAN, Costa HL, Mello JDB. Abrasioncorrosion of ferritic stainless steel In: Duriagina Z, editor. Stainless steels and alloys. 1st ed. London: IntechOpen; 2019.

22. Landolt D. Passivity issues in tribocorrosion. In: Marcus P, Maurice V, editors. Passivity issues in tribocorrosion. passivation of metals and semiconductors, and properties of thin oxide layers. Amsterdam: Elsevier; 2006. p. 477-87. https://doi. org/10.1016/B978-044452224-5/50074-3.

23. Ponthiaux P, Bayon R, Wenger F, Celis JP. Testing protocol for the study of bio-tribocorrosion. In: Yan Y, editor. Bio-tribocorrosion in biomaterials and medical implants. Cambridge: Woodhead Publishing; 2013. p. 372-94. https://doi.org/10.1533/9780857 098603.3.372.

24. Abreu D, Ardila MAN, Mello JDB. Influence of chromium content and stabilization on tribocorrosion of ferritic stainless steel. J Bio Tribo Corros. 2021;7:71. http://dx.doi.org/10.1007/ s40735-021-00507-6.

25. Cao S, Mischler S. Current opinion in solid state \& materials science modeling tribocorrosion of passive metals - a review. Curr Opin Solid State Mater Sci. 2018;22:127-41. http://dx.doi. org/10.1016/j.cossms.2018.06.001. 